\title{
The Influence of Surface Quality of Coatings on
}

\section{Their Deformation Properties}

\author{
V. I. Loganina
}

Street Titov, 28, 440028 Penza, Russia

Copyright (C) 2014 V. I. Loganina. This is an open access article distributed under the Creative Commons Attribution License, which permits unrestricted use, distribution, and reproduction in any medium, provided the original work is properly cited.

\begin{abstract}
Results of researches on influence of a roughness on deformation properties of coverings are resulted. The model of durability is offered at a stretching depending on a roughness of a surface of coverings
\end{abstract}

Keywords: defects, roughness, deformation properties, the probability of failure

\section{Introduction}

Durability coatings, among other factors depends on the quality of appearance [1, 2, 3]. The probability of destruction of protective - decorative coverings depending on presence of defects on their surface can be determined on expression:

$$
P=1-e^{-\rho S}
$$

where $\rho$ - concentration of defects;

$S$ - the area of a surface.

Apparently from the formula (1), the probability of destruction of coverings grows with increase in concentration of defects.

\section{The methodology of the experiment}

Identify patterns of influence of the surface roughness of coatings on their physical and mechanical properties of the following experiment was performed. Pellicle were made on the basis of alkyd enamel ПФ-115 and ПС-160 paint with different roughness. After complete curing of the pellicle of these samples were 
cut blade size $5,0 \times 1,0 \mathrm{~cm}$, the thickness of each sample was measured with a micrometer. The surface roughness of the coating was determined by means of the device profiler mark TR-100. Pellicle samples were tested for tensile testing machine brand ИР 50-57 with fixed crosshead speed of $87.5 \mathrm{~m} / \mathrm{s}$.

\section{Results of tests}

On fig. 1 and 2 diagrams of a stretching pellicle in coordinates «stress $\sigma$ elongation $\Delta l_{\gg}$ are submitted.

The analysis of the received data testifies, that for investigated pellicle elastic - plastic character of destruction is characteristic. Irrespective of a kind of colourful structure, with increase in a roughness of a surface plastic deformations increase and are reduced elastic (tab. 1, 2). So, for pellicle on the basis of paint $\Pi \mathrm{C}-160$ at roughness $\mathrm{Ra}=0,74$ a micron the share of elastic making deformation in the general deformation makes $\mathcal{E}_{y n p}^{\prime}=0,935$, and a share of a plastic

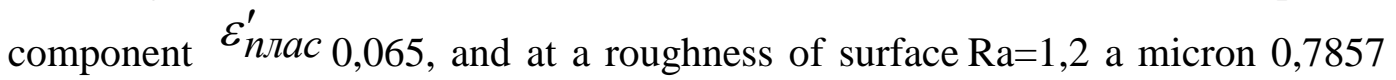
and 0,2143 accordingly. Similar laws it is traced and for pellicle on the basis of paint $\Pi \Phi-115$. At a roughness of a surface of pellicle $\mathrm{Ra}=1,2 \mathrm{mkm}$ the share of elastic making deformation makes 0,481 , and plastic - 0,519 , and at roughness $\mathrm{Ra}=1,74$ a micron accordingly 0,281 and 0,719 .

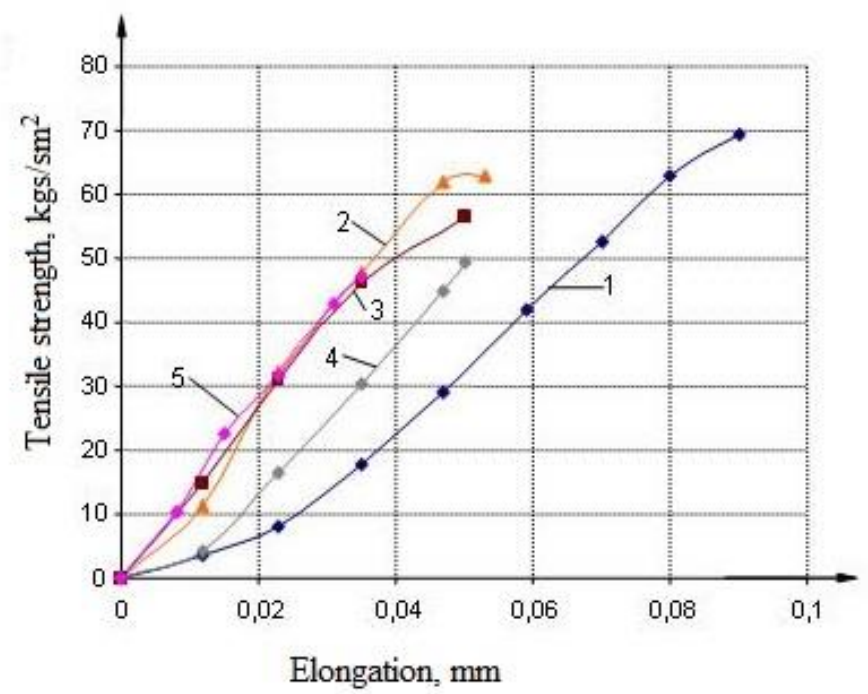

Fig. 1. Diagrams of a stretching of pellicle on the basis of paint ПС - 160 1 - a roughness 0,74 microns; 2 - a roughness 0,77 microns; 3 - a roughness 0,8 microns; 4 - a roughness 0,86 microns; 5 - a roughness 1,2 microns 


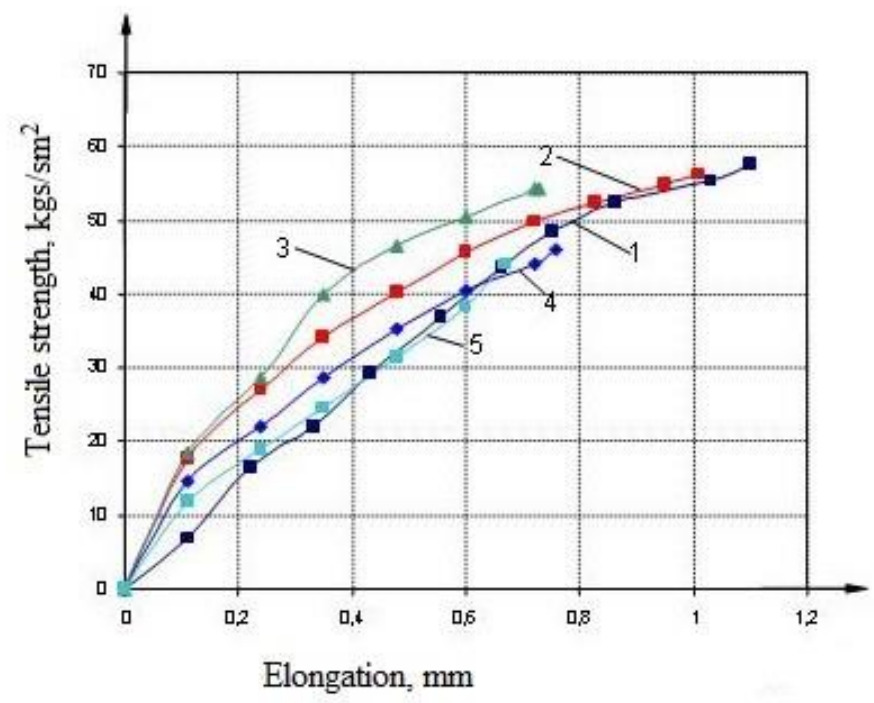

Fig. 2. Diagrams of a stretching of pellicle on the basis of paint ПФ - 115

1 - a roughness 1,2 microns; 2 - a roughness 1,37 microns;

3 - a roughness 1,45 microns; 4 - a roughness 1,54 microns;

5 - a roughness 1,74 microns

The table 1

Deformation of pellicle on the basis of paint $\Pi С-160$, depending on the surface roughness

\begin{tabular}{|c|c|c|c|c|c|c|}
\hline $\begin{array}{l}\text { Roughne } \\
\text { ss of a } \\
\text { surface } \\
\text { of a } \\
\text { pellicle, } \\
\text { Ra,mkm }\end{array}$ & $\begin{array}{l}\text { Tensile } \\
\text { strength } \\
R_{p} \\
\mathrm{kgs} / \mathrm{cm}^{2}\end{array}$ & $\begin{array}{l}\text { Relati } \\
\text { ve } \\
\text { defor } \\
\text { matio } \\
\text { ns, } \\
\varepsilon_{\text {oбw }} \\
\%\end{array}$ & $\begin{array}{c}\text { Elastic } \\
\text { deforma- } \\
\text { tions, } \\
\varepsilon_{y n p, \%}\end{array}$ & $\begin{array}{c}\text { Plastic } \\
\text { deforma- } \\
\text { tions, } \\
\varepsilon_{\text {плас }} \\
\%\end{array}$ & $\begin{array}{l}\text { The } \\
\text { proportion of } \\
\text { the elastic } \\
\text { component of } \\
\text { deformation } \\
\varepsilon_{y n p}^{\prime}\end{array}$ & $\begin{array}{c}\text { The } \\
\text { proportion of } \\
\text { plastic } \\
\text { deformation } \\
\text { component } \\
\varepsilon_{\text {плас }}^{\prime}\end{array}$ \\
\hline 0,74 & 69,4 & 3,1 & 2,9 & 0,2 & 0,935 & 0,065 \\
\hline 0,77 & 62,8 & 1,86 & 1,63 & 0,23 & 0,876 & 0,124 \\
\hline 0,8 & 56,5 & 1,8 & 1,5 & 0,3 & 0,833 & 0,167 \\
\hline 0,86 & 50,5 & 1,75 & 1,44 & 0,31 & 0,82 & 0,18 \\
\hline 1,2 & 47,2 & 1,4 & 1,1 & 0,3 & 0,7857 & 0,2143 \\
\hline
\end{tabular}


The table 2

Deformation of pellicle on the basis of paint ПФ-115, depending on the surface roughness

\begin{tabular}{|c|c|c|c|c|c|c|}
\hline $\begin{array}{c}\text { Roughn } \\
\text { ess of a } \\
\text { surface } \\
\text { of a } \\
\text { pellicle, } \\
\text { Ra,mkm }\end{array}$ & $\begin{array}{c}\text { Tensile } \\
R_{p}, \\
\mathrm{kgs} / \mathrm{cm}^{2}\end{array}$ & $\begin{array}{c}\text { Relati } \\
\text { ve } \\
\text { defor } \\
\text { ma-tio } \\
\text { ns } \\
\varepsilon_{\text {Oбu }} \\
, \%\end{array}$ & $\begin{array}{c}\text { Elastic } \\
\text { deforma- } \\
\text { tions } \\
\varepsilon_{y n p},\end{array}$ & $\begin{array}{c}\text { Plastic } \\
\text { deforma- } \\
\text { tions } \\
\varepsilon_{\text {nлac }} \\
\%\end{array}$ & $\begin{array}{c}\text { The } \\
\text { proportion of } \\
\text { the elastic } \\
\text { component of } \\
\text { deformations } \\
\varepsilon_{y n p}^{\prime}\end{array}$ & $\begin{array}{c}\text { The } \\
\text { proportion } \\
\text { of plastic } \\
\text { deforma-ti } \\
\text { ons } \\
\text { component } \\
\varepsilon_{\text {nлac }}^{\prime}\end{array}$ \\
\hline 1,2 & 57,7 & 44,3 & 21,3 & 23 & 0,481 & 0,519 \\
\hline 1,37 & 56,1 & 38 & 13,9 & 24,1 & 0,367 & 0,633 \\
\hline 1,45 & 54,3 & 28 & 9 & 19 & 0,321 & 0,679 \\
\hline 1,54 & 45,9 & 24 & 7 & 17 & 0,292 & 0,708 \\
\hline 1,74 & 44,1 & 23 & 6,44 & 16,56 & 0,281 & 0,719 \\
\hline
\end{tabular}

Found that paint pellicle based on $\Pi \mathrm{C}-160$ is characterized mainly elastic deformation. Percentage of elastic deformation component in paint pellicle based on ПС - 0,935 - 0,7857 160 is, for a paint pellicle based on the ПФ - 115 is characterized mainly plastic deformation. The proportion of plastic deformation component of 0,519-0,719.

A decrease in strength, relative deformations with increasing surface roughness of the pellicle (Fig. 3, 4). When the roughness of the pellicle $\Pi \mathrm{C}-160 \mathrm{Ra}=0,74 \mathrm{mkm}$ tensile strength of $69.4 \mathrm{~kg} / \mathrm{cm}^{2}$, the relative strain $=3.1 \%$, while the roughness of $\mathrm{Ra}=0,86 \mathrm{mkm}-50.5 \mathrm{~kg} / \mathrm{cm}^{2}$ and $1.75 \%$, respectively. When the surface roughness of the pellicle ПФ-115 $\mathrm{Ra}=0,74 \mathrm{mkm}$ tensile strength of $57.7 \mathrm{~kg} / \mathrm{cm}^{2}$, the relative deformation $=44.3 \%$, with a roughness $\mathrm{Ra}=1,74 \mathrm{mkm} \quad-44,1 \mathrm{~kg}$ / $\mathrm{cm}^{2}$ and $23 \%$, respectively.

For pellicle based on colorful compositions observed drop-down nature of the plot of "tensile strength-roughness" with a sharp decrease in strength to a certain value ( $\mathrm{R} \mathrm{p}=45-55 \mathrm{~kg} / \mathrm{cm}^{2}$ at the roughness of the pellicle based paint ПФ-115-1,4-1, 6 micrometers, and on the basis of the ink ПC-160 - 0.8-1 microns).With further increase of surface roughness of pellicle occurs a smaller reduction of the tensile strength. 


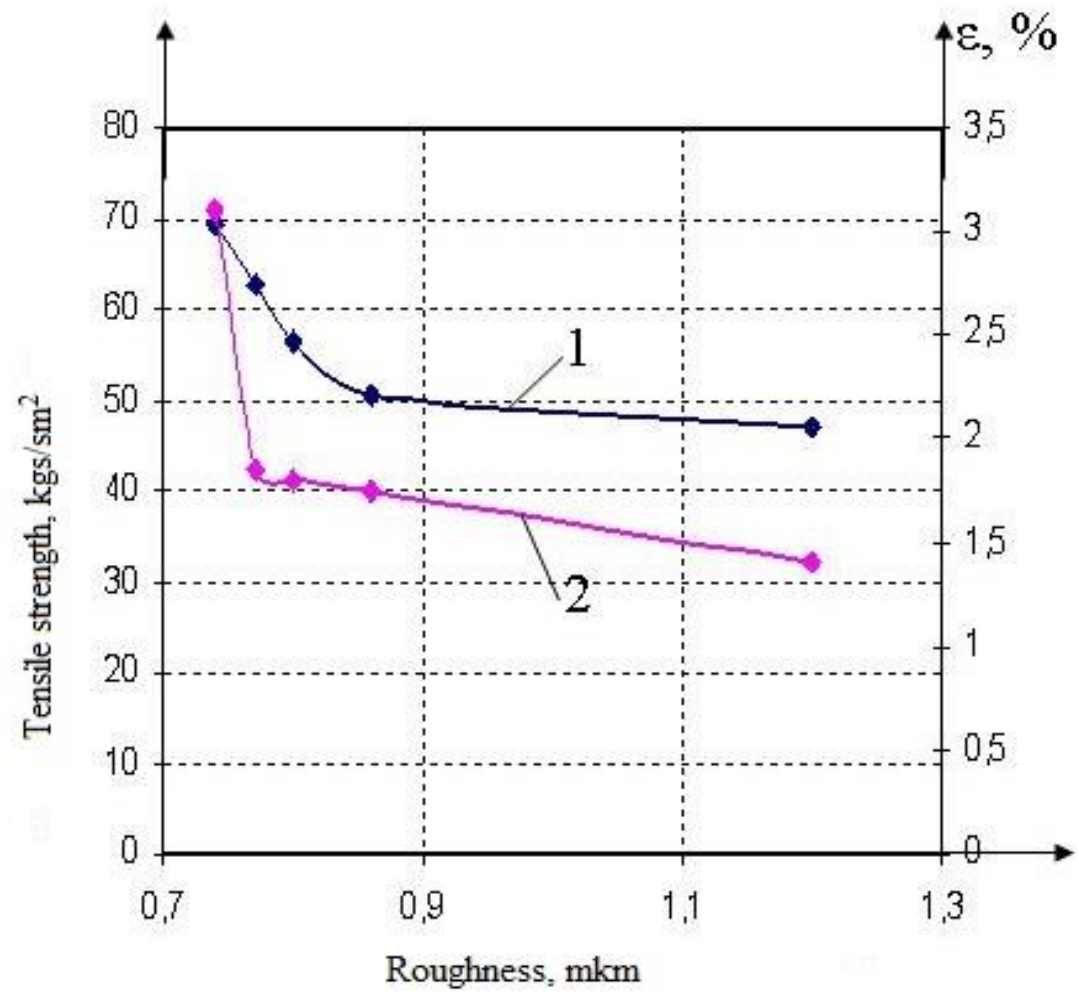

Fig. 3 Dependence of tensile strength (1) and elongation (2) the surface roughness of the pellicle paints based on ПС-160

The analysis of the data resulted on fig. 3, 4 shows, that dependence of durability at a stretching from a roughness of a surface pellicle can be approximated by expression of a kind:

$$
R_{p}=a \cdot e^{b \cdot R_{a}}
$$

where Ra - surface roughness, micrometers;

$\mathrm{b}$-factor taking into account the degree of reduction in strength of the roughness, $\mathrm{mkm}^{-1}$;

$\dot{a} \quad$ - the factor characterizes the value of tensile strength when $\mathrm{Ra}=0$ (ideal model).

For pellicle on the basis of paint ПС-160 model (2) looks like

$$
R_{p}=110,5 \cdot e^{-0,761 \cdot R_{a}}
$$

For pellicle on the basis of paint ПФ-115

$$
R_{p}=114,5 \cdot e^{-0,548 \cdot R_{a}}
$$


The submitted models allow to estimate prospective durability at a stretching depending on a roughness of a surface of coverings.

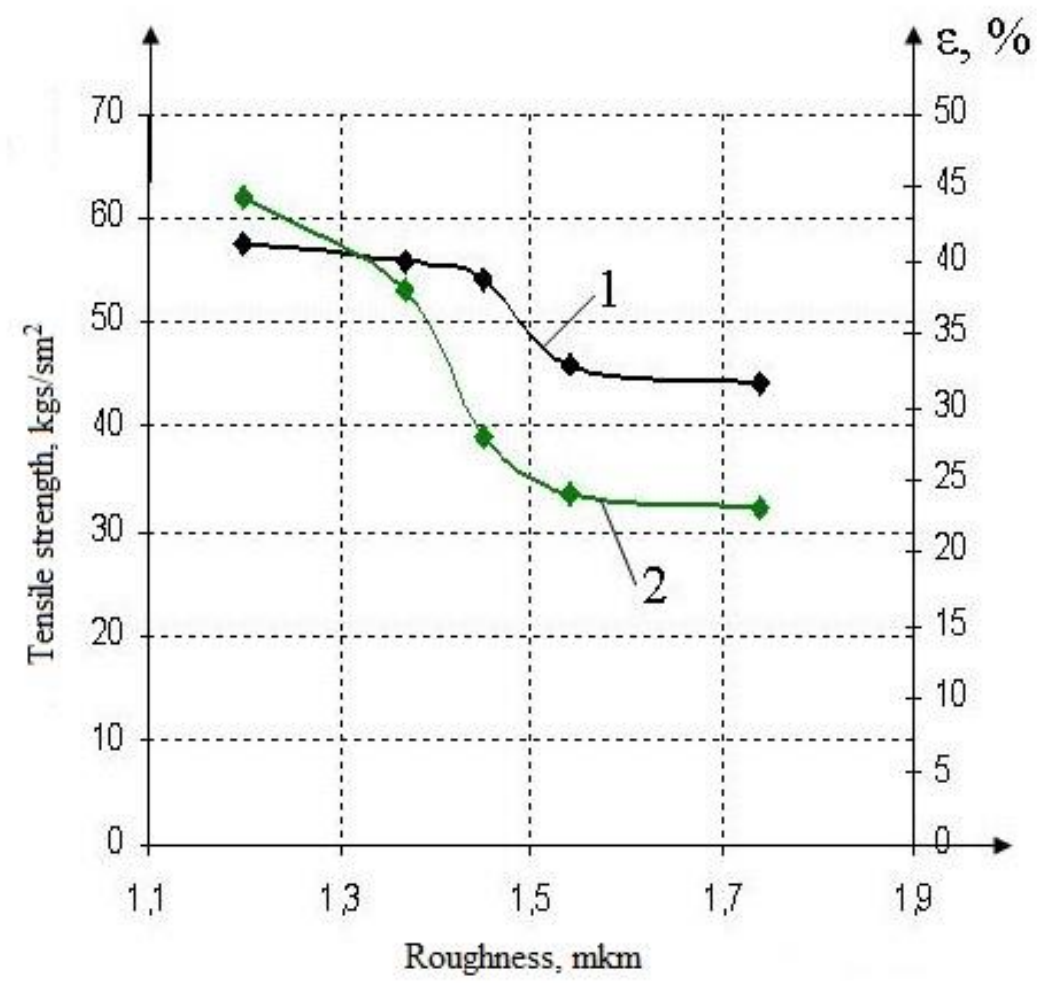

Fig. 4. Dependence of durability at a stretching (1) and relative lengthening (2) from a roughness of a surface of a pellicle on the basis of paint ПФ-115

For pellicle on the basis of paint ПС-160 model (2) looks like

$$
R_{p}=110,5 \cdot e^{-0,761 \cdot R_{a}}
$$

For pellicle on the basis of paint ПФ-115

$$
R_{p}=114,5 \cdot e^{-0,548 \cdot R_{a}}
$$

The submitted models allow to estimate prospective durability at a stretching depending on a roughness of a surface of coverings.

\section{Conclusions}

Laws of change deformation properties of protective - decorative coverings are established depending on a roughness their surfaces consisting in decrease of durability and relative deformations at increase of a roughness of a 
surface pellicle. The mathematical model of durability is offered at a stretching pellicle depending on a roughness of their surface.

\section{References}

[1] V. I. Loganina, A. A. Fedoseev, Deterioration of organic coatings under weather conditions: A statistical treatment. Lakokrasochnye Materialy $i l k h$ Primenenie, 6 (2005), 34 - 36.

[2] V. I. Loganina, A. A. Fedoseev. Failure probability law in application to the cpatings performing decorative and protective functions, Lakokrasochnye Materialy i lkh Primenenie, 10 (2002).

[3] L. P. Orentlicher, V. I. Loganina, A. A. Fedoseev. Provision of static quality acceptance control for painted surfaces of building products and structures. Promyshlennoe i Grazhdanskoe Stroite'stvo, 4 (2004), 37 - 38.

Received: November 30, 2014; Published: December 23, 2014 